\title{
Karl August Varnhagen von Ense - „szara eminencja” dziewiętnastowiecznej niemieckiej publicystyki politycznej
}

\author{
Abstract \\ Karl August Varnhagen von Ense - an "éminence grise" of German Political \\ Journalism in the $19^{\text {th }}$ Century
}

Karl August Varnhagen von Ense (1785-1858) was a German diplomat, biographer and archivist-collector. He worked as a tutor in the homes of several families of the wealthy Jewish bourgeoisie. This allowed him to get in touch with prominent poets and writers of romanticism, such as Friedrich de la Motte Fouqué, Adelbert von Chamisso, Justinus Kerner and Ludwig Uhland. During the Napoleonic Wars Varnhagen served in Austrian and Russian army. 1814 he married Rahel Levin, a Jewish writer who hosted one of the most prominent German literary salons in the late 18th and early 19th centuries. Their home in Berlin became the meeting-place of high civil servants, philosophers, writers and artists. Although Varnhagen developed a reputation as an critical writer and journalist, he is most famous as a biographer and archivist-collector. The article investigates Varnhagen's activities as a journalist and demonstrates journalism as an unknown and unexplored but significant and valuable aspekt of his work, which is substantial in volume.

Keywords: Karl August Varnhagen von Ense, Varnhagen Collection, journalism, archivist-collector, German Romanticism

Słowa kluczowe: Karl August Varnhagen von Ense, depozyt berliński, kolekcja Varnhagena, publicystyka, romantyzm niemiecki

Karl August Varnhagen von Ense (1785-1858) był niemieckim pisarzem, biografem, dyplomatą i diarystą. W młodości przebywał w Nadrenii, Strasburgu, Brukseli i Hamburgu, gdzie zetknął się z problematyką rewolucji francuskiej oraz obserwował jej następstwa. Studiował medycynę w Berlinie, Halle i Tybindze, po czym pracował jako nauczyciel domowy i wychowawca dzieci w zamożnych rodzinach mieszczańskich pochodzenia żydowskiego. Poznał wówczas wielu 
wybitnych pisarzy i poetów niemieckiego romantyzmu, wśród których byli między innymi Friedrich de la Motte Fouqué, Adelbert Chamisso, Ludwig Uhland oraz Justinus Kerner. W epoce wojen napoleońskich Varnhagen służył w armii austriackiej i rosyjskiej. Po upadku Francji towarzyszył Karlowi Augustowi von Hardenbergowi, przedstawicielowi Prus na kongresie wiedeńskim, podczas jego pobytu w stolicy Cesarstwa Austrii. Następnie został pruskim przedstawicielem dyplomatycznym w Badenii, ale już po kilku latach odwołano go ze stanowiska. Powodem były podejrzenia o sympatyzowanie z ruchem demokratycznym. W 1814 roku poślubił Rahel Levin, żydowsko-niemiecką pisarkę, która prowadziła w Berlinie słynny salon literacki.

Po śmierci żony zaczął gromadzić napisane przez nią listy. Kompletował między innymi jej korespondencję z wybitnymi przedstawicielami świata kultury i sztuki. Działalność kolekcjonerską rozpoczął jednak już znacznie wcześniej. Z czasem jego prywatne archiwum stało się obszernym zbiorem autografów. W posiadaniu Varnhagena znalazły się rękopisy ponad 9000 osób, między innymi przedstawicieli niemieckiego romantyzmu, a wśród nich Sophie Mereau, Clemensa Brentana, Bettiny i Achima von Arnimów oraz dziennikarki i poetki Helminy von Chézy ${ }^{1}$. Kolekcję odziedziczyła siostrzenica Varnhagena, Ludmilla Assing, która powiększyła zbiory o spuściznę księcia Hermanna von Pückler-Muskaua oraz pisarza Friedricha Apolloniusa von Maltitza ${ }^{2}$. W roku 1881 zbiory trafiły do Biblioteki Królewskiej w Berlinie. Od II wojny światowej duża część rękopisów znajduje się w Bibliotece Jagiellońskiej w Krakowie. Wchodzą one w skład tak zwanego depozytu berlińskiego.

Karl August Varnhagen von Ense zasłynął jako wybitny intelektualista o zainteresowaniach społeczno-politycznych, a jego zbiory zawierają cenne świadectwa historii i życia kulturalnego Berlina i Prus w XIX wieku. Nic więc dziwnego, że cieszyły i cieszą się one zainteresowaniem wielu badaczy. W zależności od okresu pochylano się nad różnymi częściami kolekcji. Stosunkowo mało uwagi poświęcano przy tym centralnej części zbiorów, związanej bezpośrednio z Karlem Augustem oraz jego żoną Rahel Varnhagen ${ }^{3}$. Można odnieść wrażenie, że o ile zgromadzone materiały zostały uznane przez potomnych za bardzo wartościowe, o tyle postać ich właściciela przez długi czas nie wzbudzała większego zainteresowania.

Varnhagen prowadził dziennik, który po jego śmierci został opublikowany dzięki staraniom niemieckiej pisarki Ludmilly Assing. Mniej znany jest fakt, iż był także płodnym publicystą. Jego twórczość przebiegała dwutorowo oraz, jak twierdzi germanistka Ursula Wiedenmann, odznaczała się wewnętrznym napię-

1 Rękopisy zostały uporządkowane alfabetycznie według nazwisk autorów, a także chronologicznie. W zbiorach znajdują się również sporządzone przez Varnhagena notki na temat autorów autografów, zapiski dotyczące ważnych wydarzeń historycznych, protokoły rozmów, ilustracje oraz druki. W roku 1911 ukazał się katalog kolekcji Varnhagena autorstwa niemieckiego egiptologa i bibliotekarza Ludwiga Sterna (zob. L. Stern, Die Varnhagen von Ensesche Sammlung in der Königlichen Bibliothek zu Berlin, Berlin 1911, s. IV-VII).

2 Zob. ibid., s. VI-VII.

3 Zob. U. Wiedenmann, Karl August Varnhagen von Ense. Ein Unbequemer in der Biedermeierzeit, Stuttgart-Weimar 1994, s. 2. 
ciem, wynikającym z rozdźwięku między diarystyką a publicystyką, między kultywowaniem prywatności a zaangażowaniem w sprawy społeczne $e^{4}$. Cechą charakterystyczną jego pracy pisarskiej było połączenie tych pozornie sprzecznych z sobą kierunków, na którym opierała się tożsamość tego człowieka pióra.

Działalność dziennikarska K.A. Varnhagena przypada na lata $1804-1858^{5}$. W skład jego bogatych zbiorów publicystycznych, obejmujących około 1600 stron, wchodzą przede wszystkim wycinki z gazet i czasopism z tego okresu' Zawierają one artykuły, które ukazały się w prasie, a także stosunkowo nieliczne rękopisy tekstów nieopublikowanych, odręczne notatki na temat wybranych artykułów oraz adnotacje dotyczące sposobu porządkowania zbiorów? . Ponadto archiwum zawiera kompletne egzemplarze gazet i czasopism oraz różnego rodzaju druki. Zebrane teksty reprezentują kilka gatunków dziennikarskich i ukazują szerokie spektrum zainteresowań ich autora. Znawca kolekcji Varnhagena, Ludwig Stern, podzielił zbiory publicystyczne na cztery opisane poniżej grupy:

1. Wybór esejów publicystycznych o tematyce politycznej z lat 1813-1819, pochodzących m.in. z periodyków „Allgemeine Zeitung”, „Deutscher Beobachter”, „Hamburger Korrespondent”. Teksty zostały wybrane i uporządkowane przez K.A. Varnhagena.

2. Eseje publicystyczne o tematyce politycznej z lat 1813-1819 z różnych gazet.

3. Artykuły polityczne z lat 1829-1831 z różnych gazet, napisane na polecenie króla Prus.

4. Strony gazet $\mathrm{z}$ artykułami z różnych lat ${ }^{8}$.

Dlaczego jednak publicystyka Karla Augusta Varnhagena jest mało znana? Czemu, w porównaniu z rezonansem wywołanym przez jego dziennik, odzew na artykuły w prasie codziennej i periodykach był stosunkowo niewielki? Dlaczego od lat sześćdziesiątych XIX wieku wielu literaturoznawców i historyków jedynie wyrywkowo zajmowało się dorobkiem publicystycznym Varnhagena, który przecież ze względu na wagę gatunkową i objętość należałoby uznać za reprezentatywny dla jego twórczości? Odpowiedzi na te pytania trzeba szukać u samego autora, który zwłaszcza w schyłkowym okresie swojego życia, mimo zaangażowania społecznego i politycznego, stronił od rozgłosu. Chciał zaszczepiać w świadomości społecznej bliskie mu idee, unikał jednak jawnej działalności politycznej'. Monachijski germanista Konrad Feilchenfeldt uważa, iż Varnhagen sam przyczynił się do tego, że z czasem o nim zapomniano. Literaturoznawca twierdzi, że berlińskiemu intelektualiście nie zależało na sławie. Chętnie nato-

4 Zob. ibid., s. 259.

5 Zob. ibid., s. 147.

6 Zgodnie z katalogiem kolekcji Varnhagena autorstwa Ludwiga Sterna, teksty publicystyczne znajdują się w pudłach o numerach 263, 264 i 265 (zob. L. Stern, op. cit., s. 847).

7 Kolekcja została uporządkowana zgodnie z zasadą chronologii przez samego K.A. Varnhagena. W niektórych miejscach porządek został zaburzony, prawdopodobnie przez późniejszych użytkowników zbiorów.

8 Zob. L. Stern, op. cit., s. 847.

9 Zob. U. Wiedenmann, op. cit., s. 143. 
miast występował w roli ,szarej eminencji”"10 i sądził, że rola ta jest jego przeznaczeniem $^{11}$. Potwierdzają to słowa, które zapisał na kartach swojego dziennika w ostatnich latach życia:

Gdy zostaję wieczorem sam i zastanawiam się nad moim stanem, moim życiem i moim dniem, nie czuję się nieszczęśliwy mimo choroby i innych braków, których doświadczam. (...) Mogę jeszcze działać, a fakt, że moje nazwisko rzadko jest wymieniane, odpowiada mi w tym samym stopniu, w jakim kiedyś byłbym $\mathrm{z}$ tego powodu niezadowolony [tłum. M. Sobczak] ${ }^{12}$.

Z perspektywy czasu można stwierdzić, że właśnie na polu publicystyki konsekwencje postawy Varnhagena są obecnie szczególnie widoczne. Już we wczesnych latach twórczości publikował on w prasie codziennej swoje artykuły. Jednak ze względu na zawarte w nich prodemokratyczne treści, uważane przez władze za niebezpieczne dla pokongresowego ładu społeczno-politycznego, ukazywały się one anonimowo. Pozornie niewyjaśniona pozostaje kwestia tekstów, za które autor nie zostałby dotknięty represjami, a które również opublikował bezimiennie. Uzasadnienia takiego postępowania należy szukać w światopoglądzie samego Varnhagena, dla którego odnajdywanie własnych myśli w przestrzeni dyskusji politycznej było ważniejsze niż kojarzenie tych myśli przez czytelników z jego osobą $^{13}$. Z biegiem lat zaznaczał on swoje autorstwo coraz rzadziej, zwłaszcza u schyłku życia. Jak wynika z przytoczonych poniżej słów, jego poglądy stopniowo ewoluowały.

Słuszny cel i prawdziwa gorliwość niweczą wszelkie samolubstwo. Dawniej patrzyłem z niechęcią na przywłaszczenie sobie przez kogoś jednej z moich myśli, dowcipu lub trafnego sformułowania. Dzisiaj rozdaję je jak bezpańskie dobra, aby każdy mógł je wziąć i z nich skorzystać. Cieszę się, ilekroć widzę, że inni je podejmują! Moje najlepsze pomysły i najdosadniejsze słowa słyszę podczas rozmów oraz odnajduję w artykułach prasowych, mowach parlamentarnych i pismach politycznych. Wówczas nie przychodzi mi na myśl, aby upomnieć się o należny mi zaszczyt. „Que nos noms périssent!” Jakże prawdziwe są słowa Dantona! [tłum. M. Sobczak] ${ }^{14}$.

10 K. Feilchenfeldt, Karl August Varnhagen von Ense, „Du Atlantis. Kulturelle Monatsschrift”, listopad 1965, $\mathrm{nr} 25$, s. 883-885, s. 885 .

11 Zob. ibid.

12 „Wenn ich Abends allein bin und mir meinen Zustand, mein Leben, meinen Tag überlege, so kann ich mich, trotz des Krankseins und so mancher andern Mängel, die ich erleide, nicht unglücklich fühlen. (...) Ich kann auch noch wirken, und daß mein Name dabei so selten vorkommt, ist mir jetzt so lieb, als es mir ehmals unlieb hätte sein können" (K.A. Varnhagen von Ense, Tagebücher von K.A. Varnhagen von Ense: aus dem Nachlaß Varnhagen's von Ense, Zürich 1865, t, 8, s. 426).

13 Zob. U. Wiedenmann, op. cit., s. 144.

14 „Ein rechtes Anliegen, ein wahrer Eifer, tödten alle Selbstsucht. Früher mocht' ich mir ungern einen Gedanken, ein Witzwort, einen gelungenen Ausdruck stehlen lassen; jetzt leg ich sie herrenlos hin, daß jeder sie nehme und gebrauche, und freue mich, so oft ich sie wiederfinde von Andern aufgenommen! Meine besten Einfälle und schärfsten Worte find' ich im Gespräch verbraucht, in Zeitungsartikeln, in Parlamentsreden, in politischen Schriften, und ich denke nicht daran, mir die Ehre davon in Anspruch zu nehmen. «Que nos noms périssent!» Wie wahr sprach Danton das!” (K.A. Varnhagen, Tagebücher..., t. 7, s. 160). 
Nawykiem Varnhagena była regularna lektura nie tylko książek, ale także prasy codziennej i czasopism. Jak mało kto lubił śledzić wydarzenia bieżące, dostrzegać i interpretować pozornie nieistotne informacje prasowe oraz docierać do najnowszych publikacji ${ }^{15}$. Niemiecki pisarz i publicysta Heinrich Laube, który znał Varnhagena z czasów, kiedy ten uczestniczył w ruchu literackim Młodych Niemiec, opisał go jako osobę o wszechstronnych zainteresowaniach, która uważnie śledziła nowinki literackie i dostrzegała związki przyczynowo-skutkowe. Laube podkreślał dużą aktywność Varnhagena na polu publicystycznym i literackim, przedstawiając go także jako człowieka zaangażowanego społecznie, który pragnął oddziaływać na opinię publiczną i pod tym kątem planował swoje przedsięwzięcia ${ }^{16}$. Z kolei Ursula Wiedenmann uważa, że rozległa wiedza, którą Varnhagen zgromadził, nie czyniła z niego wyróżniającego się wnikliwością spojrzenia obserwatora sceny politycznej i kulturalnej. Zdaniem Ursuli Wiedenmann jego diagnozy były niejednokrotnie chybione, przez co w oczach współczesnych opinie Varnhagena uchodziły za mało wiarygodne, a on sam jawił się niektórym jako gawędziarz i roznosiciel plotek ${ }^{17}$.

Pogląd ten pokutował jeszcze długo po jego śmierci. Przejęli go także niektórzy dziewiętnasto- i dwudziestowieczni literaturoznawcy. Jednym z pierwszych, którzy kwestionowali wiarygodność Varnhagena, był Rudolf Haym. Nie szczędził on Karlowi Augustowi negatywnych uwag, uważał go za człowieka bez charakteru i dopatrywał się oznak konformizmu na wszystkich polach jego działalności ${ }^{18}$. Miażdżące opinie, które Haym wyraził między innymi w recenzji pierwszych sześciu tomów dzienników Varnhagena (Tagebücher von K. A. Varnhagen von Ense), wydanych w latach 1861-1863 przez Ludmillę Assing, przez wiele dziesięcioleci oddziaływały na recepcję twórczości oraz ocenę działalności niemieckiego pisarza i publicysty ${ }^{19}$. Do grupy krytyków zaliczają się także Johannes Baptista Diel i Wilhelm Kreiten, którzy na przykładzie bliskiej znajomości Varnhagena z poetą Clemensem Brentanem opisali, w jaki sposób Karl August kontakty z wybitnymi literatami rzekomo wykorzystywał do swoich celów. Zarzucili mu, że kierując się ciekawością i żądzą sensacji, próbował zdobyć od pogrążonego w roku $1811 \mathrm{w}$ kryzysie duchowym Clemensa Brentana wiele informacji natury prywatnej, których następnie miał użyć do opisania wybitnego przedstawiciela romantyzmu w niezbyt pochlebny sposób ${ }^{20}$.

Oskarżenie Varnhagena o brak lojalności i dyskrecji pojawia się także u innych badaczy. Byli jednak również tacy, którzy zwracali uwagę na zupełnie inne aspekty działalności i związane z nimi domniemane uchybienia niemieckiego intelektualisty. Należał do nich Ludwig Geiger, który zarzucał Varnhagenowi bezprawne

15 Zob. U. Wiedenmann, op. cit., s. 146

16 Zob. H. Laube, Ausgewählte Werke, Hrsg. H.H. Houben, Leipzig 1906, t. 9, s. 338-339.

17 Zob. U. Wiedenmann, op. cit., s. 146-147.

18 Zob. R. Haym, Zur deutschen Philosophie und Literatur. Ausgewählt, eingeleitet und erläutert von Ernst Howald, Zürich/Stuttgart 1963, s. 74-173.

19 Zob. ibid.

20 Zob. J.B. Diel, Clemens Brentano. Ein Lebensbild nach gedruckten und ungedruckten Quellen. Ergänzt und herausgegeben von Wilhelm Kreiten, t. 1, Freiburg im Breisgau 1877, s. 343. 
przechwytywanie cennych rękopisów, posługiwanie się nieuczciwymi metodami oraz brak rzetelności w zakresie korzystania z dostępnych mu źróde ${ }^{21}$. Natomiast dwudziestowieczny literaturoznawca Friedrich Römer nie negował wprawdzie zasług Varnhagena jako kolekcjonera, literata i publicysty, ale uważał, że Karl August zawdzięczał pozycję $\mathrm{w}$ świecie kultury nie tyle własnym osiągnięciom, ile sławie żony, Rahel Varnhagen (z domu Levin), pisarki i jednej z najwybitniejszych kobiet tamtej epoki ${ }^{22}$.

Jaki był stosunek K.A. Varnhagena do niemieckiego romantyzmu? Niewątpliwie nie należał on do grona pierwszoplanowych przedstawicieli tego nurtu. Gdy jednak przyjrzymy się dokładniej jego działalności, zauważymy, że rola, którą odegrał, była nie do przecenienia. Ze środowiskiem niemieckich romantyków łączyła go już w okresie wczesnego romantyzmu - tak zwanego romantyzmu jenajskiego (1795-1804) - przynależność do stowarzyszenia literackiego Nordsternbund, założonego przez Adelberta von Chamisso ${ }^{23}$. Wśród członków stowarzyszenia znaleźli się prominentni twórcy kultury i sztuki, tacy jak Friedrich de la Motte Fouqué, August Ferdinand Bernhardi, Heinrich Julius Klaproth, Julius Eduard Hitzig, David Ferdinand Koreff, Ludwig Robert, Franz Theremin i Wilhelm Neumann. Powstało ono jako pokłosie cyklu wykładów Augusta Wilhelma Schlegla zatytułowanych Über schöne Literatur und Kunst, wygłoszonych w Berlinie w latach 1801-1804. Razem z Adelbertem von Chamissem Varnhagen redagował rocznik stowarzyszenia „Der Grüne Almanach”, natomiast w roku 1807 ukazała się wydana dzięki współpracy z Wilhelmem Neumannem antologia zatytułowana Erzählungen und Spiele.

Varnhagenowi można przypisać jeszcze jedną zasługę: pozostając w tle głównych wydarzeń tego okresu, pośredniczył w nawiązywaniu kontaktów między artystami a przedstawicielami innych sfer społecznych. Inspirował i inicjował rozmaite przedsięwzięcia, pozostawiając realizację planów innym, wybitniejszym od niego. Za przykład działalności Varnhagena niech posłuży salon literacki, który w latach 1819-1833 prowadził w Berlinie wraz ze swoją żoną 24 . W spotkaniach odbywających się w miejscach zamieszkania małżeństwa uczestniczyły osoby z różnych środowisk. Wśród gości byli przede wszystkim twórcy i krytycy literatury, osoby związane z szeroko pojętą kulturą i sztuką, ale także arystokraci, politycy i mieszczanie pochodzenia żydowskiego, słowem: ludzie, którzy ze względu na bariery stanowe i różnice majątkowe poza salonem artystycznym nie mieli prawa się spotkać. Osoby te łączył jednak nie tylko progresywny światopo-

21 Zob. L. Geiger, Berlin 1688-1840. Geschichte des geistigen Lebens der preußischen Hauptstadt, t. 2, Berlin 1895, s. 572-574.

22 Zob. F. Römer, Varnhagen von Ense als Romantiker, rozprawa doktorska, Berlin 1934, s. 5.

23 Zob. Nordsternbund [w:] Encyclopedia Britannica, https://www.britannica.com/topic/Nordsternbund (dostęp: 20.07.2020).

24 Karl August Varnhagen poślubił Rahel Levin w roku 1814, natomiast pięć lat później małżonkowie przenieśli się do Berlina, gdzie założyli salon literacki istniejący do roku 1833. W latach 1819-1827 spotkania odbywały się w domu przy Französische Straße 20, potem natomiast przy Mauerstraße 36 (zob. H.T. Tewarson, Rahel Levin Varnhagen: The Live and Work of a German Jewish Intellectual, Lincoln-London 1998, s. 181). 
gląd, lecz także - zwłaszcza w ostatnich latach funkcjonowania salonu - sympatia dla ruchu literackiego Młodych Niemiec. Varnhagenowie stwarzali swoim gościom możliwość dyskusji na różne tematy, a ich salon uważany był powszechnie za przestrzeń swobodnej i autentycznej wymiany myśli ${ }^{25}$. Do stałych bywalców należeli między innymi bracia Wilhelm i Alexander von Humboldtowie, Georg Wilhelm Friedrich Hegel, Adelbert von Chamisso, Franz Leopold Ranke, książę Hermann von Pückler-Muskau, Bettina i Achim von Arnimowie, Heinrich Heine, E.T.A. Hoffmann, Carl Ludwig Börne oraz Eduard Gans ${ }^{26}$.

Warto pamiętać, że nie zawsze K.A. Varnhagen prowadził tak bogate życie towarzyskie. Istniały bowiem również momenty, w których trzymał się z dala od „wielkiego świata”. Dotyczy to zwłaszcza niektórych okresów w przedziale czasowym 1833-1858. Życie w odosobnieniu nie było dla Varnhagena równoznaczne z odcięciem się od środowiska intelektualnego. Utrzymywał on kontakty zwłaszcza z ludźmi kultury i sztuki, ale także ze środowiskiem szlacheckim i mieszczańskim, arystokracją, politykami i działaczami społecznymi. Rozległe znajomości umożliwiały mu zdobywanie informacji, które następnie wykorzystywał w swoich tekstach publicystycznych. Sieć kontaktów towarzyskich funkcjonowała jak agencja informacyjna ${ }^{27}$. Dzięki niej Varnhagen docierał do istotnych wiadomości, zanim jeszcze pojawiły się one $\mathrm{w}$ prasie. W tym celu nawiązywał kontakty z ludźmi, którzy mogli je dostarczyć, na przykład z osobami należącymi do kręgów dworskich albo funkcjonującymi ze względu na pełnioną funkcję lub zajmowane stanowisko w różnych środowiskach społecznych ${ }^{28}$. Możliwość nawiązywania kontaktów była niejednokrotnie ograniczona różnicami pochodzenia i przynależności stanowej. Jako platformy wymiany informacji sprawdzały się salony artystyczno-literackie, w których spotykali się przedstawiciele różnych stanów.

Varnhagen zapoczątkował strategię zdobywania wiadomości dzięki kontaktom towarzyskim jeszcze w okresie wojen napoleońskich. Kontynuował swoją działalność podczas kongresu wiedeńskiego, w trakcie pobytów w Paryżu oraz po przeprowadzce do Karlsruhe ${ }^{29}$. Do grupy prominentnych informatorów, z którymi nawiązał kontakt głównie na początku swojej kariery, należeli tacy politycy i publicyści, jak Friedrich Karl von Tettenborn, Georg Ulrich von Otterstedt, Georg von Cotta, Friedrich Christoph Perthes, Ignaz Paul Vital Troxler, Konrad Engelbert Oelsner, Friedrich Ludwig Lindner oraz Heinrich Luden ${ }^{30}$. Najbliższych przyjaciół Varnhagena, ale także inne osoby należące do grona jego znajomych, łączyło przekonanie o dużych możliwościach oddziaływania na opinię publiczną za pośrednictwem prasy. Łączyły ich także podobne poglądy

25 Zob. P. Wilhelmy, Der Berliner Salon im 19. Jahrhundert (1780-1914) [w:] Veröffentlichungen der Historischen Kommission zu Berlin, t. 73, Berlin-New York 1989, s. 434.

26 Zob. ibid.

27 Zob. U. Wiedenmann, op. cit., s. 305.

28 Zob. ibid., s. 306.

29 Zob. ibid., s. 306-307.

30 Zob. ibid., s. 307. 
społeczno-polityczne, głównie o charakterze liberalnym ${ }^{31}$. Wymiana myśli odbywała się przede wszystkim na drodze codziennej korespondencji. O dużej aktywności epistolarnej i produktywności publicystycznej świadczą precyzyjne zapiski Varnhagena wchodzące w skład jego zbiorów rękopiśmienniczych.

Istnieją także inne czynniki, które przyczyniły się do tego, że Varnhagen nie zapisał się w pamięci czytelników jako wybitny publicysta. Jednym z nich jest fakt, że nie udało mu się zostać wydawcą lub redaktorem naczelnym żadnego liczącego się periodyku. Wprawdzie u schyłku okresu wojen napoleońskich redagował i wydawał on „Zeitung aus dem Feldlager”, a także nadawał ton w piśmie „Deutscher Beobachter”, które ukazywało się w latach 1813-1819, jednak obie gazety były jedynie „efemerycznymi świadectwami” ${ }^{32}$ jego działalności na polu publicystyki.

Lata poprzedzające kongres wiedeński były nie tylko początkiem, ale również najpłodniejszym okresem w pracy publicystycznej Varnhagena. Inspirowała go świadomość uczestnictwa w ważnych wydarzeniach, bycia poniekąd w centrum wielkiej historii. Problematyką tak zwanych wojen wyzwoleńczych zajmował się jednak nie tylko w okresie służby w sztabie generała kawalerii Friedricha Karla von Tettenborna. Również w latach 1816-1819 opisywał on swoje wspomnienia z pobytu na froncie $\mathrm{e}^{33}$.

Cechą charakterystyczną pierwszego etapu pracy publicystycznej Varnhagena było korzystanie z szerokiej palety gatunków literackich. W wydawanej przez niego gazecie frontowej zamieszczane były wiersze, czego przykładem może być utwór jego autorstwa zatytułowany Johanna Stegen in Lüneburg. Jest on poświęcony bohaterskim czynom młodej kobiety, Johanny Stegen, w bitwie pod Lüneburgiem 2 kwietnia 1813 roku $^{34}$. Z czasem lirykę zaczęły wypierać teksty prozatorskie, które dokumentując ważne wydarzenia wojenne, prawdopodobnie lepiej odpowiadały na oczekiwania czytelników. Trend polegający na odejściu w prasie od poezji (prymat funkcji estetycznej) na rzecz prozy publicystycznej (dominacja funkcji informacyjnej) był zjawiskiem charakterystycznym dla ostatniej fazy niemieckiego romantyzmu oraz początku okresu biedermeieru. Zmiany, jakie zaszły w „Zeitung aus dem Feldlager”, wpisują się zatem w szerszy kontekst zjawisk obejmujących dużą część ówczesnej prasy niemieckojęzycznej ${ }^{35}$.

31 Przekonania społeczno-polityczne małżeństwa Varnhagenów ewoluowały. Identyfikacja z państwem pruskim oraz lojalność wobec monarchii Hohenzollernów miały dla nich jednak znaczenie fundamentalne. Wiązało się to m.in. z pochodzeniem żydowskim Rahel Varnhagen, która podobnie jak większość zasymilowanych Żydów w Królestwie Prus żyła w obawie przed oskarżeniem o brak patriotyzmu i kosmopolityzm. (zob. J. Schoeps, Von der Untertanenloyalität zum Bürgerpatriotismus. Preußen, die Juden und die Anfänge des Identifikationsprozesses zu Beginn des 19. Jahrhunderts [w:] Das Emanzipationsedikt von 1812 in Preußen. Der lange Weg der Juden zu ,Einländern” und „,preußischen Staatsbürgern” / Europäisch-jüdische Studien. Beiträge, t. 15, Hrsg. I.A. Diekmann, Berlin-Boston 2013, s. 9-10).

32 U. Wiedenmann, op. cit., s. 261.

33 Zob. ibid., s. 274.

34 Zob. S.A. Mustafa, Germany in the Modern World: A New History, Lanham 2016, s. 102-103.

35 Zob. U. Wiedenmann, op. cit., s. 291. 
Zgodnie z postanowieniami kongresu wiedeńskiego wszystkie państwa członkowskie nowo utworzonego Związku Niemieckiego, w skład którego weszły także Prusy, miały przyjąć własne konstytucje. Obietnica realizacji tego zobowiązania, złożona także przez króla Prus Fryderyka Wilhelma III, nie została jednak spełniona. Również jego następca, Fryderyk Wilhelm IV, blokował początkowo prace nad ustawą zasadniczą. Dopiero pod presją wydarzeń rewolucji marcowej w roku 1848 król oktrojował konstytucję, rozwiązując uprzednio Zgromadzenie Narodowe ${ }^{36}$.

Dla Varnhagena ofiarna walka ludności wszystkich stanów przeciwko Francji Napoleona Bonaparte pociągała za sobą konieczność rewanżu ze strony monarchów w postaci nadania poszczególnym państwom niemieckim konstytucji. Jego zdaniem wojny wyzwoleńcze powinny były doprowadzić w Niemczech do ostatecznej likwidacji reliktów starej struktury społecznej z czasów ancien régime’u, które przetrwały okres zawirowań 1789-1799. Jak twierdził Varnhagen, w roku 1815 przyszedł czas na kontynuację procesu przemian społeczno-politycznych, który ku jego dużemu rozczarowaniu utknął w miejscu. Rozpoczynająca się epoka restauracji była dla niego okresem publicystycznej refleksji nad przyczynami i konsekwencjami stagnacji, a także czasem poszukiwań możliwości przełamania impasu oraz częstych powrotów do wspomnień z frontu.

Niepowodzeniem skończyła się dla Varnhagena próba założenia pruskiej gazety państwowej. Pomysł ten zrodził się jeszcze w czasach kongresu wiedeńskiego, kiedy to publicysta doszedł do wniosku, że rząd powinien zajmować stanowisko w ważnych sprawach i komunikować się z opinią publiczną za pośrednictwem prasy. Poglądy na sposób porozumiewania się władz państwowych ze społeczeństwem Varnhagen wyraził w memoriale skierowanym do rządu Królestwa Prus ${ }^{37}$. Pismo to nie tylko ilustruje zapatrywania intelektualisty na ważne dla ogółu sprawy, ale także pozwala wyciągnąć wnioski na temat roli, jaką Varnhagen chciał odegrać w owym czasie. Była to rola pośrednika między władzą państwową a społeczeństwem, które pod wpływem przemian zapoczątkowanych jeszcze przed rewolucją francuską osiągnęło - jak uważał Varnhagen - dojrzałość, natomiast w okresie wojen wyzwoleńczych udowodniło swoją lojalność wobec monarchii pruskiej. Oba te fakty wymuszały na władzy zdaniem Varnhagena konieczność traktowania społeczeństwa jako partnera, którego należy respektować. Publicysta uważał, że niezadowoleniu wynikającemu z anachronicznej polityki państwa będzie można zapobiec poprzez powołanie sprawnie działającego organu prasowego, którego zadaniem byłoby szybkie informowanie opinii publicznej o planach i posunięciach rządu ${ }^{38}$. Warto zauważyć, że próbując dotrzeć do kręgów decyzyjnych, Varnhagen poddał urzędnikom państwowym myśl o wykorzystaniu do wywierania wpływu na społeczeństwo tych samych środków, którymi już wcześniej skutecznie posługiwały się siły opozycyjne. Równocześnie plan

36 Zob. F. Ebel, „,Der papierne Wisch“: Die Bedeutung der Märzrevolution 1848 für die preußische Verfassungsgeschichte, Berlin-New York 1998, s. 5-9.

37 Zob. U. Wiedenmann, op. cit., s. 261-262.

38 Zob. ibid. 
realizacji strategii wymiany informacji między władzą a społeczeństwem nie był pozbawiony idealizmu opartego na hasłach rewolucji francuskiej.

Ewolucja światopoglądu Varnhagena w epoce restauracji coraz bardziej oddalała go od elit państwowych, a coraz bardziej przybliżała do środowisk opozycyjnych. Te zaś toczyły w tym okresie walkę o wyłonienie na drodze demokratycznych wyborów organów przedstawicielskich i uchwalenie konstytucji obywatelskiej. Zabiegano także o zjednoczenie państw Związku Niemieckiego. Idea przyjęcia konstytucji oraz cel utworzenia wspólnego państwa niemieckiego zaczęły z czasem łączyć progresywnych intelektualistów. Im silniejsze stawały się tendencje restauracyjne w oficjalnej polityce państwowej, tym podejrzliwiej przedstawiciele aparatu władzy patrzyli na Varnhagena i jego otoczenie ${ }^{39}$. Coraz bardziej nasilał się konflikt między zwolennikami kursu reakcyjnego a liberałami.

Varnhagen, podobnie jak wielu ówczesnych publicystów dbał, o anonimowość swoich artykułów prasowych. Opracowano różne strategie skutecznego zacierania śladów umożliwiających dotarcie do autorów publikacji. Tekstów nie wysyłano wprost do redakcji gazet. Doręczano je za pośrednictwem osób trzecich, które je uprzednio przepisywały. Manuskrypty natomiast niszczono. W korespondencji posługiwano się szyframi, a redakcje nie wypłacały honorariów autorom artykułów, tylko podstawionym osobom. Nawet po przeanalizowaniu zachowanych dokumentów księgowych znanego wydawnictwa Cotta'sche Verlagsbuchhandlung, zawierających informacje o honorariach dla autorów artykułów, które ukazały się w gazetach „Allgemeine Zeitung” i „Morgenbatt”, nie udałoby się obecnie określić, kim w rzeczywistości byli autorzy tych tekstów ${ }^{40}$.

Poprzez publicystykę Varnhagen wywarł z pewnością większy wpływ na czytelników niż przez inne formy swojej aktywności literackiej. Patrząc na jego twórczość z dzisiejszej perspektywy, można jednak zauważyć, że po śmierci długofalowym zainteresowaniem cieszyły się jego dzienniki. Wynikało to przede wszystkim z braku dostępu czytelników do tekstów publicystycznych Varnhagena. Podczas gdy dzienniki doczekały się publikacji w formie książkowej, wydanie zebranych tekstów prasowych nigdy nie wyszło poza fazę koncepcyjną. Varnhagen zachował z myślą o ponownym wydaniu wiele artykułów, które ukazywały się w różnych okresach jego życia, jednak śmierć uniemożliwiła mu publikację zbioru.

Wstęp do planowanego wydania tekstów prasowych ilustruje przemianę poglądów Varnhagena między początkiem a końcem jego działalności publicystycznej. O ile w pierwszych latach podążał on niejednokrotnie za aktualnymi trendami w publicystyce i literaturze, o tyle później zdołał się wybić na większą niezależnośćc ${ }^{11}$. Przemierzył niełatwą drogę od wiary w siłę oddziaływania prasy na władze państwowe i społeczeństwo do postawy nacechowanej większym sceptycyzmem oraz ostrożnością. Jawną działalność zastąpił systematycznym,

39 Zob. ibid., s. 307-308.

40 Zob. D. Moran, Toward the Century of Words. Johann Cotta and the Politics of the Public Realm in Germany 1795-1832, Berkeley-Los Angeles-Oxford 1990, s. 198-219.

${ }^{41}$ Zob. U. Wiedenmann, op. cit., s. 305. 
ukrytym wywieraniem wpływu na opinię publiczną. Nauczył się czerpać satysfakcję z drobnych działań przynoszących skromne, ale trwałe i wymierne efekty. Świadczy o tym następująca wypowiedź, zaczerpnięta ze wspomnianego wstępu:

Dzięki ogromnemu zwielokrotnieniu moich artykułów, które ukazywały się we wszystkich miejscach i krajach, w rozmaitych gazetach, (...) moje poglądy nieuchronnie (...) wywierały silny wpływ [na opinię publiczną - przyp. aut.] [tłum. M. Sobczak ${ }^{42}$.

Warto zaznaczyć, że nie zgromadził wszystkich tekstów publicystycznych, które napisał. Obecnie odnalezienie tych brakujących, podobnie zresztą jak jednoznaczne określenie autorstwa licznych anonimowych artykułów z ówczesnej prasy, jest prawie niemożliwe ${ }^{43}$. Nie istnieją nawet wiarygodne szacunki dotyczące ogólnej liczby tekstów prasowych autorstwa Varnhagena. Stąd też wielu literaturoznawców i historyków nie miało odwagi, aby podjąć się zadania przeprowadzenia kompleksowych badań nad jego dorobkiem publicystycznym. W konsekwencji ta ważna dla Varnhagena działalność, jaką była publicystyka, pozostała białą plamą na mapie jego twórczości ${ }^{44}$. Otwarte pozostaje pytanie, jaką rolę odgrywały jego artykuły prasowe na tle publicystyki okresu biedermeieru oraz późnego romantyzmu. Nie wiadomo też, czy miały one jakikolwiek wpływ na recepcję jego twórczości w drugiej połowie XIX wieku.

Literaturoznawcy zwracają uwagę na bliskie pokrewieństwo gatunkowe, merytoryczne i stylistyczne artykułów prasowych oraz tekstów diarystycznych Varnhagena, powstałych w podobnych okresach jego życia. Rozbieżności są często niewielkie i można odnieść wrażenie, że zapiski w dzienniku stanowią antycypację niejednej myśli zawartej w nieco późniejszych artykułach prasowych ${ }^{45}$. Równocześnie ślady tekstów publicystycznych w postaci aluzji, reminiscencji, parafraz, cytatów, analogii oraz kontrastów odnajdujemy w tekstach literackich jego autorstwa. Liczne związki intertekstualne świadczą o tym, że Varnhagen nie traktował publicystyki jako działalności drugoplanowej. Warto zauważyć, że czasami przytaczał on nawet długie fragmenty swoich artykułów lub wznawiał starsze publikacje prasowe. Przykładem ponownego wydania tekstów publicystycznych w postaci recenzowanego zbioru jest dzieło Zur Geschichtschreibung und Litteratur, które ukazało się w Hamburgu w roku $1833^{46}$.

Podczas gdy dwudziestowieczni badacze podkreślali zasługi Karla Augusta Varnhagena jako wybitnego kolekcjonera, który zachował dla przyszłych pokoleń wiele wartościowych rękopisów z epoki romantyzmu, nie doceniali oni jego twór-

42 „Bei der ungeheuren Vervielfachung meiner Artikel, die von allen Orten und Ländern her datirt, in den mannigfachen Blättern zum Vorschein kamen (...) konnte es nicht fehlen, daß meine ausgesprochenen Ansichten (...) ihre kräftige Wirkung übten" (szkic wstępu do wydania zbiorowego artykułów prasowych K.A. Varnhagena [w:] C. Misch, Varnhagen von Ense in Beruf und Politik, Gotha-Stuttgart 1925, s. 163).

43 Praktyka publikowania anonimowych artykułów w prasie była w pierwszej połowie XIX wieku szeroko rozpowszechniona (zob. U. Wiedenmann, op. cit., s. 7).

44 Zob. ibid., s. 263-264.

45 Zob. ibid., s. 264-265.

46 Zob. K.A. Varnhagen von Ense, Zur Geschichtschreibung und Litteratur. Berichte und Beurtheilungen von K. A. Varnhagen von Ense, Hamburg 1833. 
czości piśmienniczej. Nie szczędzili mu też krytycznych uwag. Padały one także pod adresem jego dorobku publicystycznego, którego nie mieli przecież szansy w całości poznać. Dzisiejsi literaturoznawcy są wstrzemięźliwsi w wydawaniu nieprzychylnych sądów, a lekceważące postawy wobec berlińskiego intelektualisty należą obecnie raczej do rzadkości. Prawdopodobnie obiektywna i całościowa ocena jego publicystyki nie będzie jednak nigdy możliwa.

Praca dziennikarska Varnhagena oraz wielu jemu współczesnych intelektualistów miała przede wszystkim oddziaływać na opinię publiczną i kształtować sposób myślenia społeczeństwa w ten sposób, aby utorować drogę dla przemian w duchu demokratycznym. Publikując anonimowo, byli oni gotowi podporządkować swojej misji potrzebę uzyskania uznania ze strony czytelników. To nie postać autora stała w centrum ich tekstów, ale sama misja społeczna, do realizacji której chcieli oni dążyć nawet za cenę utraty praw do własnego dorobku. Varnhagen wyrażał zadowolenie z popularności swoich ocen i poglądów, które - jak twierdził - szeroko kolportowano w ówczesnej prasie ${ }^{47}$.

Ta wymuszona niesprzyjającymi okolicznościami „skromność autorska” stanowiła nie tylko znaczne utrudnienie dla cenzury. Przysparza ona problemów także współczesnemu literaturoznawstwu, dla którego „autor” i „dzieło” są kategoriami kluczowymi. Warto zaznaczyć, że to właśnie w pierwszej połowie XIX wieku zaczęto doceniać i podkreślać znaczenie autora oraz chronić jego prawa do tekstów spod jego pióra. Jeśli dzieło było anonimowe, niejednokrotnie popadało ono w zapomnienie, gdyż ważnym warunkiem jego wznowienia było powiązanie tekstu z postacią autora ${ }^{48}$. Kategorie ,autora bez dzieła” i „dzieła bez autora” nie mieściły się w polu zainteresowań dziewiętnastowiecznego i po części także dwudziestowiecznego literaturoznawstwa.

Przez długi czas patrzono podejrzliwie również na zaangażowanie polityczne Varnhagena. Pisząc anonimowo i nie zajmując ważnego stanowiska politycznego, nie miał, zdaniem współczesnych, legitymacji społecznej. Niejednokrotnie zarzucano mu grafomanię i asekuranctwo. Dla intelektualistów, takich jak Heinrich von Treitschke, Rudolf Haym i Arno Schmidt, Varnhagen zachowywał się jak człowiek bez charakteru, który nie chciał wziąć na siebie odpowiedzialności za głoszone przekonania ${ }^{49}$. Ich zdaniem, niejako z definicji, nie można było polemizować z poglądami anonimowego autora. Zważywszy jednak na niebezpieczeństwo, na które progresywny publicysta narażał się w dobie reakcji, sądy te wydają się zbyt ostre.

O ile na początku swojej działalności Karl August Varnhagen ulegał w dziedzinie publicystyki różnym modom, o tyle później wybił się na niezależność i wypracował swój charakterystyczny styl. Dzięki zdobytemu doświadczeniu stał się suwerennym dziennikarzem. Występując w roli „szarej eminencji” publicystyki, dał się poznać jako płodny i utalentowany autor. Nawet jeśli rekonstrukcja jego dorobku jest w znacznej mierze utrudniona w wyniku braku możliwości dotarcia

47 Zob. C. Misch, op. cit., s. 163.

48 Zob. U. Wiedenmann, op. cit., s. 309-310.

49 Zob. ibid., s. 311. 
do części artykułów, to przed współczesnym literaturoznawstwem otwiera się ciekawe pole do badań nad dostępnymi tekstami.

\section{Bibliografia}

Diel J.B., Clemens Brentano. Ein Lebensbild nach gedruckten und ungedruckten Quellen. Ergänzt und herausgegeben von Wilhelm Kreiten, t. 1, Freiburg im Breisgau 1877.

Ebel F., „, Der papierne Wisch“: Die Bedeutung der Märzrevolution 1848 für die preuBische Verfassungsgeschichte, Berlin-New York 1998.

Feilchenfeldt K., Karl August Varnhagen von Ense, „Du Atlantis. Kulturelle Monatsschrift", listopad 1965, nr 25, s. 883-885.

Geiger L., Berlin 1688-1840. Geschichte des geistigen Lebens der preußischen Hauptstadt, tom 2, Berlin 1895.

Haym R., Zur deutschen Philosophie und Literatur. Ausgewählt, eingeleitet und erläutert von Ernst Howald, Zürich-Stuttgart 1963.

Laube H., Ausgewählte Werke. Hrsg. von Heinrich Hubert Houben, t. 9, Leipzig 1906.

Misch C., Varnhagen von Ense in Beruf und Politik, Perthes, Gotha-Stuttgart 1925.

Moran D., Toward the Century of Words. Johann Cotta and the Politics of the Public Realm in Germany 1795-1832, University of California Press, Berkeley-Los Angeles-Oxford 1990.

Mustafa S.A., Germany in the Modern World: A New History, Lanham 2016.

Nordsternbund [w:] Encyclopedia Britannica, https://www.britannica.com/topic/ Nordsternbund (dostęp: 20.07.2020).

Römer F., Varnhagen von Ense als Romantiker, rozprawa doktorska, Berlin 1934.

Schoeps J., Von der Untertanenloyalität zum Bürgerpatriotismus. Preußen, die Juden und die Anfänge des Identifikationsprozesses zu Beginn des 19. Jahrhunderts [w:] Das Emanzipationsedikt von 1812 in Preußen. Der lange Weg der Juden zu „Einländern” und „preußischen Staatsbürgern” / Europäisch-jüdische Studien. Beiträge, t. 15, Hrsg. I.A. Diekmann, Berlin-Boston 2013, s. 6-19.

Stern L., Die Varnhagen von Ensesche Sammlung in der Königlichen Bibliothek zu Berlin, Berlin 1911.

Tewarson H.T., Rahel Levin Varnhagen: The Live and Work of a German Jewish Intellectual, University of Nebraska Press, Lincoln-London 1998.

Varnhagen von Ense K.A., Tagebücher von K.A. Varnhagen von Ense: aus dem Nachlaß Varnhagen's von Ense, wyd. Ludmilla Assing, Zürich 1865.

Varnhagen von Ense K.A., Zur Geschichtschreibung und Litteratur. Berichte und Beurtheilungen von K.A. Varnhagen von Ense, Perthes, Hamburg 1833.

Wiedenmann U., Karl August Varnhagen von Ense. Ein Unbequemer in der Biedermeierzeit, Metzler, Stuttgart-Weimar 1994.

Wilhelmy P., Der Berliner Salon im 19. Jahrhundert (1780-1914) [w:] Veröffentlichungen der Historischen Kommission zu Berlin, t. 73, Berlin-New York 1989. 
